\title{
6: Myanmar's economic relations with China: who benefits and who pays?
}

\author{
Toshihiro Kudo
}

\section{Introduction}

Against the background of closer diplomatic, political and security ties between Myanmar and China since 1988, their economic relations have also become stronger throughout the 1990s and up to the present. China is now a major supplier of consumer and capital goods to Myanmar, in particular through border trade. China also provides a large amount of economic cooperation in the areas of infrastructure, state-owned economic enterprises (SEEs) and energy. Nevertheless, Myanmar's trade with China has failed to have a substantial impact on its broad-based economic and industrial development. China's economic cooperation apparently supports the present regime, but its effects on the whole economy are limited. At worst, bad loans might need to be paid off by Myanmar and Chinese stakeholders, including taxpayers. Strengthened economic ties with China will be instrumental in regime survival, but will not be a powerful force affecting the process of economic development in Myanmar.

Myanmar and China call each other 'paukphaw', a Myanmar word for siblings. Paukphaw is not used for any other foreign country, reflecting Myanmar and China's close and cordial relationship. ' For Myanmar, China has historically been by far its most important neighbour, sharing the longest border, of 2227 kilometres. Myanmar regained its independence in 1948 and quickly welcomed the birth of the People's Republic of China in the next year. The Sino-Myanmar relationship has always been premised on five principles of peaceful coexistence, which include mutual respect for each other's territorial integrity and sovereignty and mutual non-aggression (Than 2003).

Nevertheless, independent Myanmar has been cautious about its relationship with China. In reality, Sino-Myanmar relations have undergone a series of ups and downs and China has occasionally posed a real threat to Myanmar's security, such as the incursion of defeated Chinese Nationalist (Kuomintang or KMT) troops into the northern Shan State in 1949, overt and covert Chinese support for the Burmese Communist Party's insurgency against Yangon up until 1988 and confrontations between Burmese and resident overseas Chinese, including militant Maoist students in 1967. Indeed, the Myanmar leadership, always extremely sensitive about the country's sovereignty, independence and territorial 
integrity, had long observed strict neutrality during the Cold War, avoiding obtaining military and economic aid from the superpowers.

Dramatic changes have emerged since the birth in 1988 of the present government, the State Peace and Development Council (SPDC), originally called the State Law and Order Restoration Council (SLORC). The United States, the European Union, Japan and multilateral aid organisations all withheld official development assistance and some Western countries imposed political sanctions and weapons embargoes after 1990. Under mounting international pressure, the military regime in Yangon had no choice but to approach Beijing for help. As diplomatic, political and security ties between the two countries grew closer, economic relations also strengthened.

The purpose of this chapter is to examine the development of and changes in Myanmar-China economic relations since 1988 and to evaluate China's growing influence on the Myanmar economy. It seeks to answer the question of whether or not the Myanmar economy can survive and grow with reinforced economic ties with China. In other words, can China support the Myanmar economy against the imposition of economic sanctions by Western countries? This question is relevant to assess the impact and effectiveness of sanctions. The chapter also tries to answer another question - namely, who benefits in what ways and who pays what costs as the two countries strengthen their ties, in spite of Myanmar's isolation from the mainstream of the international community.

The second section introduces a brief history of how the two countries have become the closest of allies since 1988. The third section examines trade relations between Myanmar and China, while the fourth section describes Chinese economic and business cooperation with Myanmar. The last section summarises the author's arguments and answers the research questions.

\section{Historical and political background}

For many years, China adopted a dual-track approach towards Myanmar by endorsing party-to-party relations between the Chinese Communist Party (CCP) and the Burmese Communist Party (BCP), in addition to maintaining state-to-state relations. The CCP's covert and overt support of the BCP, which resorted to armed struggle against the Yangon government soon after its independence, seriously hindered the two countries' state-to-state relationship for many years after Myanmar's independence.

When the military took power in a coup in 1988, thousands of pro-democracy activists, including students, fled to the border area near Thailand, where numerous ethnic insurgencies were active (Lintner 1998). ${ }^{2}$ None of the ethnic rebels there could, however, secure a meaningful amount of armaments. On the other hand, unlike the ethnic insurgents, the BCP located along the Chinese border had access to vast quantities of arms and ammunition that were supplied 
by China. Hypothetically, an alliance of pro-democracy activists, ethnic rebels and an armed BCP might have posed a potential threat to Myanmar's military government, but it was not to happen.

Instead, a mutiny caused the BCP to split into four ethnic groups in early 1989. The CCP had already withdrawn its active support of the BCP after 1985 (Than 2003). Just before the end of the Cold War, China departed from its dual-track diplomacy and renounced its policy stance favouring the BCP. Having lost Beijing's backing, the BCP collapsed in the year after the establishment of the SLORC. ${ }^{3}$ On the other hand, Yangon was fortunate to secure Beijing's backing in the midst of Western ostracism.

The mutiny inside the BCP provided a golden opportunity for the Myanmar military to neutralise the newly emerged armed groups, and they were willing to pay any price for this. Lieutenant-General Khin Nyunt, then Secretary No. 1 of the SLORC, wasted no time in going to the Chinese border and he achieved a successful cease-fire with these groups. Under the terms of the cease-fire, the Myanmar Government offered the former BCP mutineers development assistance such as roads, bridges, power stations, schools and hospitals as well as business opportunities, including mining and lumbering concessions and border trade. As Bertil Lintner, veteran South-East Asia correspondent, writes:

Ironically, at a time when almost the entire population of Burma had turned against the regime, thousands of former insurgents thus rallied behind the ruling military. The threat from the border areas was thwarted, the regime was safe, but the consequences for the country, and the outside world, were disastrous. (Lintner 1998:170)

Than Shwe, then Vice-Chairman of the SLORC, accompanied by Khin Nyunt, visited Beijing in October 1989 and laid the foundations for the current partnership between the two countries. The visit also marked a departure from Myanmar's past policy on arms imports, whereby it eschewed large arms purchases from the superpowers consistent with its policy of strict neutrality (Jannuzi 1998). The SLORC apparently launched an ambitious plan to enlarge and modernise the Tatmadaw, the Myanmar armed forces, by late 1988 or early 1989, with heavy reliance on Chinese armaments (Selth 1996). At the same time, the military leadership successfully extracted a promise of economic and technical cooperation from China.

Without the change in China's diplomacy towards Myanmar and the break up of the BCP, the relationships and structures of power would not have reached their present points. Arms transfers and economic ties have dramatically increased China's influence over Myanmar. Indeed, a few years of military and economic aid have turned the non-aligned state of Myanmar into China's closest ally. 
Today, the military government is effectively dependent on China for its survival and, some analysts say, it has become a Chinese client state (Ott 1998).

\section{Trade relations}

\section{China as an important but unbalanced trading partner}

China occupies an important position in Myanmar's external trade. Tables 6.1 and 6.2 show the major trading partners of Myanmar since 1980. According to the tables, China has consistently occupied a high ranking, since Myanmar-Chinese border trade-hitherto an activity deemed illegal-was legitimised and formalised in 1988. China's fifth position in this trade constituted 8.1 per cent of Myanmar's total exports to the rest of the world and 20.6 per cent of its total imports from the rest of the world (ranking China first in 1990), ${ }^{4}$ although Myanmar's volume of external trade was small at that time. Since then, Myanmar's trade with China has grown rapidly.

Table 6.1 Myanmar's major export partners (per cent)

\begin{tabular}{|l|l|l|l|l|l|l|}
\hline & $\mathbf{1 9 8 0}$ & & $\mathbf{1 9 8 8}$ & & $\mathbf{1 9 9 0}$ & \\
\hline $\mathbf{1}$ & Singapore & $\mathbf{1 4 . 3}$ & Africa & 19.7 & Africa & 14.3 \\
\hline $\mathbf{2}$ & Africa & 10.6 & Singapore & 9.7 & Thailand & 12.0 \\
\hline $\mathbf{3}$ & Japan & 9.9 & Hong Kong & 9.1 & Singapore & 11.3 \\
\hline $\mathbf{4}$ & Indonesia & 9.5 & Japan & 8.4 & India & 10.8 \\
\hline $\mathbf{5}$ & Hong Kong & $\mathbf{7 . 6}$ & Indonesia & 7.0 & China & 8.1 \\
\hline & $\mathbf{1 9 9 5}$ & \multicolumn{2}{|l|}{$\mathbf{2 0 0 0}$} & $\mathbf{2 0 0 8}$ & \\
\hline $\mathbf{1}$ & Singapore & 16.0 & United States & 22.4 & Thailand & 49.0 \\
\hline $\mathbf{2}$ & India & 12.2 & Thailand & 11.8 & India & 12.1 \\
\hline $\mathbf{3}$ & China & 11.3 & Africa & 8.6 & Africa & 5.8 \\
\hline $\mathbf{4}$ & Africa & 9.3 & India & 8.2 & China & 5.3 \\
\hline $\mathbf{5}$ & Indonesia & 8.0 & China & 5.7 & Japan & 5.1 \\
\hline
\end{tabular}

Source: International Monetary Fund, Direction of Trade.

Table 6.2 Myanmar's major import partners (per cent)

\begin{tabular}{|c|c|c|c|c|c|c|}
\hline & 1980 & & 1988 & & 1990 & \\
\hline 1 & Japan & 43.7 & Japan & 39.0 & China & 20.6 \\
\hline 2 & \begin{tabular}{|l|} 
United \\
Kingdom
\end{tabular} & 8.8 & $\begin{array}{l}\text { United } \\
\text { Kingdom }\end{array}$ & 9.1 & Singapore & 17.9 \\
\hline 3 & Germany & 7.4 & Germany & 6.7 & Japan & 16.6 \\
\hline 4 & Singapore & 6.1 & United States & 6.0 & Germany & 4.8 \\
\hline 5 & United States & 5.0 & Singapore & 5.8 & Malaysia & 4.7 \\
\hline & 1995 & & 2000 & & 2006 & \\
\hline 1 & Singapore & 29.9 & Thailand & 18.3 & China & 34.0 \\
\hline 2 & China & 29.0 & China & 18.0 & Thailand & 21.4 \\
\hline 3 & Malaysia & 10.8 & Singapore & 15.8 & Singapore & 15.8 \\
\hline 4 & Japan & 7.4 & South Korea & 10.5 & Malaysia & 4.6 \\
\hline 5 & South Korea & 4.1 & Malaysia & 8.4 & South Korea & 4.0 \\
\hline
\end{tabular}

Source: International Monetary Fund, Direction of Trade. 
Myanmar's imports from China grew more rapidly than its exports to China throughout the 1990s and up to 2006. Figure 6.1 clearly shows the unbalanced nature of Myanmar's exports to and imports from China. While Myanmar's exports to China increased by 6.9 times, from \$US33.3 million in 1990 to \$US229.7 million in 2006, its imports from China expanded by 9.6 times, from \$US137.7 million in 1990 to \$US1.328 billion in 2006, resulting in a huge trade deficit of \$US1.098 billion in 2006, which was 2.4 times larger than Myanmar's total trade surplus of \$US451.4 million in the same year.

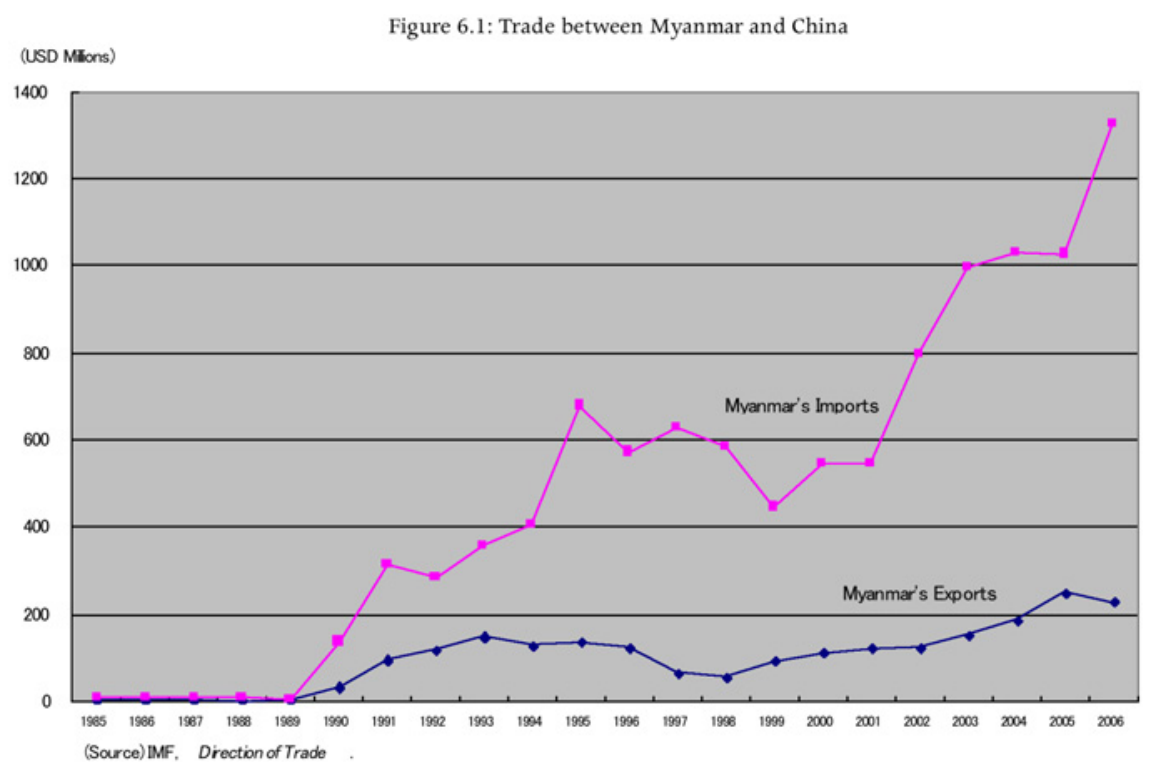

\section{Exports: weak impacts on the economic development of Chinese trade}

Myanmar's exports to China comprise mostly wood, gemstones and fruit and nuts (Table 6.3). Myanmar has, however, become more and more dependent on wood exports, the share of which occupied nearly 70 per cent of the total for the period 2000-03. ${ }^{5}$ According to Chinese Customs data, this trend continued through $2007 .{ }^{6}$ Wood accounted for 69 per cent of exports in 2004, 71 per cent in 2005, 60 per cent in 2006 and 51 per cent in 2007. In contrast, the share of gemstones declined to a few per cent by the early 2000s, probably because of the government's export restrictions. Wood is exported mostly in the form of logs or roughly sawn timber without much human and technical input. Such a high dependency on timber has made the levels of Myanmar's exports to China rather stagnant, since this trade is constrained by the availability of natural resources. 
Table 6.3 Myanmar's major exports to China (per cent)

\begin{tabular}{|l|l|l|l|l|l|}
\hline Rank & Items & $\mathbf{1 9 8 8 - 9 1}$ & $\mathbf{1 9 9 2 - 9 5}$ & $\mathbf{1 9 9 6 - 9 9}$ & $\mathbf{2 0 0 0 - 0 3}$ \\
\hline $\mathbf{1}$ & $24^{\text {a }}$ Cork and wood & 7.4 & 40.8 & 43.7 & 67.7 \\
\hline $\mathbf{2}$ & 05 Vegetables and fruit & 14.6 & 5.5 & 3.0 & 8.1 \\
\hline $\mathbf{3}$ & 28 Metalliferous ores and metal scrap & 3.8 & 4.3 & 6.2 & 4.8 \\
\hline $\mathbf{4}$ & $\begin{array}{l}\text { 27 Crude fertilisers and crude materials (excluding } \\
\text { petroleum etc.) }\end{array}$ & 0.2 & 0.2 & 8.0 & 4.0 \\
\hline $\mathbf{5}$ & 66 Non-metallic mineral manufactures, n.e.s. & 20.8 & 30.8 & 24.6 & 3.6 \\
\hline $\mathbf{6}$ & $\begin{array}{l}\text { 03 Fish, crustaceans, molluscs, preparations } \\
\text { thereof }\end{array}$ & 9.7 & 5.0 & 1.9 & 3.3 \\
\hline $\mathbf{7}$ & $\begin{array}{l}29 \text { Crude animal and vegetable materials, not } \\
\text { elsewhere specified }\end{array}$ & 8.7 & 3.6 & 3.6 & 2.1 \\
\hline $\mathbf{8}$ & 22 Oil seeds and oleaginous fruit & 9.0 & 1.3 & 1.0 & 1.5 \\
\hline $\mathbf{9}$ & $\begin{array}{l}23 \text { Crude rubber (including synthetic and } \\
\text { reclaimed) }\end{array}$ & 0.1 & 0.1 & 0.2 & 1.2 \\
\hline $\mathbf{1 0}$ & $\begin{array}{l}\text { 63 Cork and wood manufactures (excluding } \\
\text { furniture) }\end{array}$ & 0.1 & 0.5 & 0.2 & 0.5 \\
\hline
\end{tabular}

a Standard International Trade Classification (SITC) numbers Source: UN Comtrade Database.

More importantly, various studies have identified wood extraction and its export in the form of logs as having had a weak impact on broad-based economic and industrial development, because it fails to generate improved utilisation of existing factors of production, expanded factor endowments or positive linkage effects. This contrasts sharply with Myanmar's other newly emerged export products in the 1990s, such as beans and pulses for Indian markets and garments for the US and EU markets - both of which had a considerable impact on the national economy. Fujita and Okamoto (2006) explain that the cultivation of beans and pulses grew rapidly by mobilising previously untapped domestic resources, including arable land and labour in the dry season. The sudden emergence of export markets provided farmers and merchants with incentives to utilise idle resources more fully and effectively. Such an export-driven development path is termed 'vent for surplus' by Myanmar economist Hla Myint (1959). Garment exports can be described similarly, for which the United States and the European Union presented big export markets, and untapped unemployed and underemployed labour were mobilised from urban and rural areas for this extremely labour-intensive industry. ${ }^{7}$

Contrasting with these examples, wood extraction and log exports that dominated Myanmar-China trade have not produced broad-based economic growth with the development of value-added wood-based industries downstream. Moreover, the Myanmar Government does not seem to pay due attention to the sustainability of wood extraction and export. Some specialists warn that unless effective controls against excessive logging are implemented, Myanmar will lose one of its major exports in the foreseeable future (see, for example, Global Witness 2005). 
In order to enhance imports from Cambodia, Laos, Myanmar and Vietnam (known collectively as CLMV), China began its Early Harvest Plan (EHP) under the ASEAN-China Free Trade Agreement (ACFTA) in January 2004. The EHP with the Association for South-East Asian Nations (ASEAN) covered about 600 agricultural products and China and ASEAN's six advanced members agreed to reduce tariffs on these products to zero within three years, while CLMV should eliminate their tariffs no later than 2010 (Hao 2008). China also initiated special preferential tariff programs under the EHP and exempted 133 products from Myanmar from January 2004 and 87 items from January 2006. The benefits of such programs for Myanmar are, however, not yet obvious, as shown in Figure 6.1 .

\section{Imports: China as a major supply source}

Soon after the opening up of border trade in 1988, China appeared in trade statistics as a major supplier of commodities and goods to the Myanmar economy. Myanmar's imports from China have increased since then, although imports have experienced ups and downs, as shown in Figure 6.1.

Imports experienced rapid growth on three occasions: once in the first half of the 1990s, again at the beginning of the twenty-first century and in 2006. Accordingly, Myanmar has become more and more dependent on imports from China. The share of Chinese goods in Myanmar's total imports rose from about one-fifth in 1990 to about one-third in 2006.

The first rapid growth of Chinese imports resulted from the unleashing of pent-up demand from the Myanmar population after the open-door policy begun in 1988 . Myanmar people had long been cut off from daily consumer goods and durables during the socialist period. Once they achieved access, the demand for such goods shot up (Kudo 2005a). While consumer goods made up 6 per cent and 12 per cent of total imports in the fiscal years ${ }^{8} 1980 / 81$ and 1985/86 respectively, the corresponding figures shot up to 35 per cent in fiscal year 1990/91 and to 42 per cent in 1995/96 (Central Statistical Organisation 2003). China provided the main source of supply and Chinese products poured into the emerging consumer-goods markets in Myanmar.

Just after the opening up of border trade with China, textiles (mostly yarn and fabrics) flooded onto Myanmar markets (Table 6.4). Textiles occupied nearly 40 per cent of total imports from China for the period 1988-91. Tobacco then increased its share, up to 14 per cent for the subsequent period 1992-95. Road vehicles, power generators, electrical machinery and apparatus, and manufactures of metal, each accounted for about 5 per cent in the first half of the 1990s.

Entering the second half of the 1990s, however, the inflow of Chinese imports stagnated. The Myanmar Government became annoyed with the country's expanding trade deficits by the mid-1990s and resorted to stricter import controls, 
particularly on luxury and non-essential goods. Accordingly, the influx of Chinese consumer goods and durables declined. Textiles and tobacco provide two examples: the former decreased its share of total imports from China from 38 per cent for the period 1988-91 to 16 per cent for the period 1996-99; the latter declined from 14 per cent for the period 1992-95 to 6 per cent for the period 1996-99.

\section{Table 6.4 Myanmar's major imports from China (per cent)}

\begin{tabular}{|l|l|l|l|l|l|}
\hline Rank & Items & $\mathbf{1 9 8 8 - 9 1}$ & $\mathbf{1 9 9 2 - 9 5}$ & $\mathbf{1 9 9 6 - 9 9}$ & $\mathbf{2 0 0 0 - 0 3}$ \\
\hline $\mathbf{1}$ & 65 Textile yarn, fabrics, made-up articles & 37.7 & 19.8 & 16.2 & 18.1 \\
\hline $\mathbf{2}$ & 71 Power-generating machinery and equipment & 3.6 & 4.5 & 5.7 & 8.5 \\
\hline $\mathbf{3}$ & 78 Road vehicles (including air-cushion vehicles) & 3.7 & 6.1 & 4.0 & 7.5 \\
\hline $\mathbf{4}$ & 72 Machinery specialised for particular industries & 1.0 & 2.6 & 7.2 & 6.3 \\
\hline $\mathbf{5}$ & 77 Electrical machinery, apparatus and appliances & 5.1 & 4.6 & 5.1 & 5.8 \\
\hline $\mathbf{6}$ & 74 General industrial machinery and equipment & 0.6 & 0.9 & 3.2 & 5.6 \\
\hline $\mathbf{7}$ & $\begin{array}{l}\text { 33 Petroleum, petroleum products and related } \\
\text { articles }\end{array}$ & 4.5 & 4.3 & 2.8 & 5.2 \\
\hline $\mathbf{8}$ & 69 Manufactures of metal, n.e.s. & 5.4 & 4.1 & 6.5 & 5.1 \\
\hline $\mathbf{9}$ & 67 Iron and steel & 3.6 & 4.5 & 3.8 & 4.5 \\
\hline $\mathbf{1 0}$ & $\begin{array}{l}\text { 76 Telecommunications and sound-recording } \\
\text { equipment }\end{array}$ & 2.0 & 1.4 & 1.0 & 2.7 \\
\hline
\end{tabular}

a Standard International Trade Classification (SITC) numbers Source: UN Comtrade Database.

In contrast, imports of capital and intermediate goods steadily increased throughout the 1990s. These goods were supplied to the emerging manufacturing sector for import substitution in Myanmar. For example, machinery and transport equipment (SITC 7) ${ }^{9}$ increased its share from 12 per cent for the period 1988-91 to 40 per cent for the period 1996-99. Imported textiles (SITC 65) had been used not only for domestic consumption but as raw materials for the growing export-oriented garment industry since the mid-1990s. A garment industry 'boom' occurred in Yangon in the late 1990s and at the beginning of the twenty-first century. The rapid growth of the garment industry in Myanmar was supported partly by raw-material supplies from China.

Myanmar's imports from China showed rapid growth for the second time at the beginning of the twenty-first century. Imports grew at the average annual rate of 22.7 per cent for the period 2000-03. Textiles, road vehicles, power generators, electrical machinery and apparatus and general industrial machinery increased their shares of total imports from China.

Such an increase could reflect the huge inflow of Chinese economic cooperation and commercial loans. As will be discussed later in this chapter, Chinese economic cooperation expanded, in particular towards the end of the 1990s, when successive economic and technical cooperation programs were signed between the two countries. Most of these were tied, whether legally or de facto, to supply 
from Chinese companies, and state-owned enterprises in particular, and thus stimulated imports from China.

\section{Border trade: the main artery of the Myanmar economy}

Trade between Myanmar and China is heavily dependent on cross-border trade. According to the district-specific export and import figures from China Customs, ${ }^{10}$ coastal areas such as Shanghai, Shenzhen, Huangpu and Nanjing naturally occupy the major share of China's external trade. In contrast, Kunming, capital of Yunnan Province, accounts for less than 1 per cent of China's external trade.

Since Yunnan is a landlocked province, commodities exported to or imported from Myanmar through the Kunming Customs Office are most likely transported by land through border gates such as Muse, Lwejel and Laiza. ${ }^{11}$ We therefore regard the commodities that are cleared and recorded at the Kunming Customs Office as 'border trade' in this chapter. ${ }^{12}$ This means that the border trade between the two countries makes up less than 1 per cent of China's external trade.

Even though the volume of border trade between the two countries is insignificant compared with China's total external trade, it represents the lion's share of China's trade with Myanmar. Border trade made up about 50 per cent of China's exports to Myanmar and about 70 per cent of its imports from Myanmar during the period 2000-07 (Table 6.5). Moreover, Yunnan Province's share of Myanmar's total border trade was 73 per cent, whereas that of Thailand was 14 per cent in the fiscal year 2003/04 (Than 2005). Border trade is important for Myanmar and for Yunnan Province.

Table 6.5 China's border trade with Myanmar (\$US million)

\begin{tabular}{|l|l|l|l|l|l|l|l|l|}
\hline & 2000 & 2001 & 2002 & 2003 & 2004 & 2005 & 2006 & 2007 \\
\hline $\begin{array}{l}\text { Exports } \\
\text { via } \\
\text { border }\end{array}$ & 293.5 & 261.2 & 358.3 & 446.3 & 500.6 & 540.6 & 656.0 & 800.4 \\
\hline $\begin{array}{l}\text { Percentage } \\
\text { of total } \\
\text { exports) }\end{array}$ & 59.1 & 52.5 & 49.4 & 49.1 & 53.3 & 57.8 & 54.3 & 47.3 \\
\hline $\begin{array}{l}\text { Imports } \\
\text { via } \\
\text { border }\end{array}$ & 66.9 & 93.7 & 105.4 & 134.5 & 164.5 & 223.5 & 166.8 & 231.6 \\
\hline $\begin{array}{l}\text { Percentage } \\
\text { of total } \\
\text { imports) }\end{array}$ & 53.6 & 69.8 & 77.0 & 79.3 & 79.5 & 81.5 & 66.0 & 62.5 \\
\hline
\end{tabular}

Note: China's border trade is defined as commodities cleared and recorded by the Kunming Customs Office. Source: China Customs.

The main route of border trade on Myanmar soil is the 460-kilometre-long road connecting Muse on the Chinese border (opposite Ruili in Yunnan Province) and Mandalay, Myanmar's second-largest city, in central Myanmar. This road constituted a part of the old 'Burma Road' that opened in 1936 to supply the 
KMT government in Chungking. The road was paved and expanded for truck transportation in 1998 on a build-operate-transfer (BOT) basis by Asia World, one of the biggest private business conglomerates, headed by a son of the former drug lord Lo Hsing-Han. ${ }^{13}$ Before the completion of the new road, travel from Mandalay to Muse took a couple of days and sometimes even a week during the rainy season; it now takes only 12-16 hours by motor vehicle.

Border trade between the two countries has experienced ups and downs, reflecting not only market situations but political, security and macroeconomic conditions in a broader sense. It also sometimes falls prey to illegitimate business, corruption and power struggles. It is well known that the ouster of former Prime Minister General Khin Nyunt in October 2004 originated from a clash between intelligence and army units in Muse (Hlaing 2005). Nevertheless, in spite of these ups and downs, border trade between the two countries has been legitimised, regularised and institutionalised.

The first border-trade agreement was signed in August 1988 by Myanmar Export and Import Services (MEIS) and Yunnan Machinery Import Export Corporation to use bank transactions between the Myanmar Foreign Trade Bank and the Kunming Branch of China Bank. MEIS established border-trade offices in Lashio, Muse, Kyugok, Namkhan and Koonlon. According to notification from the Ministry of Commerce (no. 7/91), MEIS implemented the so-called new border-trade system in October 1991. ${ }^{14}$ The Myanmar and Chinese Governments signed a formal border-trade agreement in August 1994. A border-trade office was established in Muse in August 1995 and introduced 'one-stop services' on a trial basis. The office was extended to the fully fledged Border Trade Department of the Ministry of Commerce in August 1996. In July 1997, the Export First Policy was applied to border trade as well as to seaborne trade, and imports were allowed only against export earnings thereafter. From November 1997, all border trade had to use US dollars to settle transactions, not local currencies such as the Myanmar kyat and the Chinese yuan. In January 1998, the Muse office was expanded and started to function as a one-stop-service border gate.

Further policy changes occurred towards the end of 2000. From November 2000, local currencies - namely, the Myanmar kyat and the Chinese yuan-could again be used for payments in border trade. From January 2001, the Border Control Force (Na Sa Kha) started to supervise and implement border-trade activities. This force was led by a military intelligence officer and comprised all related organisations, including immigration, customs, the internal-revenue department, police, drug-control offices, the Myanmar Economic Bank, and so on. The ostensible purpose of the force was to promote border trade in a systematic manner. In reality, however, military intelligence monopolised the most lucrative 
route for border trade, which eventually led to a major clash within the regime's leadership in 2004.

The regularisation and institutionalisation of cross-border transactions and further road development contributed to boosting border trade between the two countries at the beginning of the twenty-first century. China's exports to Myanmar through border posts increased by 3.1 times, from \$US261.2 million in 2001 to \$US800.4 million in 2007, whereas China's imports from Myanmar via border trade expanded by 2.5 times, from \$US93.7 million in 2001 to \$US231.6 million in 2007. The Myanmar Government also promoted all border trade not only with China but with Thailand, India and Bangladesh, to compensate for the economic sanctions imposed by the West, and the Chinese border recorded the most meaningful success. Myanmar's border trade with China has therefore become a main artery of its economy.

\section{Economic and business cooperation}

China and Chinese enterprises are heavily involved in Myanmar's industrial, infrastructure and energy development through economic cooperation. China is not a member country of the Development Assistance Committee (DAC) of the Organisation for Economic Cooperation and Development (OECD) and it does not disclose its economic cooperation programs. The Myanmar Government also does not disclose details of its receipt of economic assistance from abroad. We can only estimate the facts from reports appearing sporadically in the press. China's economic cooperation programs are often nothing more than commercial-based business. Even though Chinese enterprises offer suppliers credits at no or low interest, in reality they add the cost to the plants and commodities they export to Myanmar (Ebashi 2006). On the other hand, most Chinese economic cooperation programs are tied to Chinese firms, and state-owned enterprises in particular. It is difficult to distinguish genuine economic cooperation projects from commercial ones without detailed information. This section includes both cases.

Gathering information from such scattered sources shows that China's provision of economic cooperation to Myanmar seems to have expanded from about 1997 when the United States imposed economic sanctions that banned new foreign investments. Appendix 1 shows the list of agreements on economic and technical cooperation signed between the two countries after 1996. Moreover, Senior-General Than Shwe's state visit to Beijing in January 2003 seemingly marked another epoch, when China offered Myanmar a preferential loan amounting to \$US200 million and a grant of \$US6.25 million. Just after China's commitment, the so-called 'Black Friday' of 30 May 2003 occurred (when Daw Aung San Suu Kyi was attacked by pro-regime elements), an event that prompted the United States to impose stricter sanctions in July 2003, which included an import ban on all Myanmar-made products. China stepped into the vacuum 
created by the Western sanctions and compensated for Myanmar's needs for trade and economic cooperation.

It is said that China's foreign aid, or economic cooperation, is motivated by two main objectives: to secure a favourable environment in its neighbours and to secure natural resources - energy in particular (Kobayashi 2007). Both of these factors are critically important for the Chinese economy to grow and for China to become a global economic power. Myanmar is a suitable partner under both criteria. Accordingly, Myanmar is one of the major recipients of Chinese economic cooperation (Table 6.6). It was the third-largest recipient of Chinese economic cooperation in 2000, receiving \$US186.7 million, and ninth largest in 2005, receiving \$US289.8 million - which was about three times more than the total amount of assistance provided by the DAC member countries in the same year.

Table 6.6 China's economic cooperation, 2000 and 2005 (\$US million)

\begin{tabular}{|l|l|l|l|l|l|l|}
\hline & & \multicolumn{1}{|c|}{$\mathbf{2 0 0 0}$} & & & \multicolumn{1}{|c|}{$\mathbf{2 0 0 5}$} & \\
\hline & Country & Turnover & Resources & Country & Turnover & Resources \\
\hline $\mathbf{1}$ & Pakistan & 329.4 & Coal, gas & Sudan & 1342.8 & Oil, gas \\
\hline $\mathbf{2}$ & Bangladesh & 231.2 & Coal, gas & Nigeria & 799.9 & Oil, gas \\
\hline $\mathbf{3}$ & Myanmar & $\mathbf{1 8 6 . 7}$ & Oil, gas & Pakistan & 751.4 & Coal, gas \\
\hline $\mathbf{4}$ & Sudan & 118.8 & Oil, gas & Bangladesh & 614.0 & Coal, gas \\
\hline $\mathbf{5}$ & Mali & 105.1 & Gold & Indonesia & 534.6 & Oil, gas \\
\hline $\mathbf{6}$ & Yemen & 97.9 & Oil, gas & India & 412.9 & Coal, iron ore \\
\hline $\mathbf{7}$ & Laos & 93.7 & Potassium & Angola & 305.7 & Oil, diamonds \\
\hline $\mathbf{8}$ & Zimbabwe & 87.6 & - & Vietnam & 299.2 & Bauxite, coal \\
\hline $\mathbf{9}$ & Vietnam & 87.5 & Bauxite, coal & Myanmar & $\mathbf{2 8 9 . 8}$ & Oil, gas \\
\hline $\mathbf{1 0}$ & Sri Lanka & 63.6 & - & Egypt & 276.5 & Oil, gas \\
\hline
\end{tabular}

Source: Adapted from Kobayashi (2007:130).

China's economic cooperation and business dealings with Myanmar were directed to three main fields: infrastructure development, support for SEEs and energy exploitation.

\section{Infrastructure}

Among the many infrastructure projects financed and constructed by the Chinese Government and Chinese enterprises, attention is immediately directed to those of electric-power generation. Myanmar has suffered a severe shortage of electricity since the end of the 1990s and the government has initiated massive dam-building programs for hydro-power generation. ${ }^{15}$ According to a foreign businessman in Yangon, Chinese companies constructed six hydro-power plants and one thermal power station in the period between 1996 and 2005, the installed capacity of which constituted about one-third of the entire national capacity (Ebashi 2006).

Among these, the Paunglaung Hydro-Power Project in central Myanmar clearly showed the financial, managerial and technical capabilities of Chinese companies in this field. It was completed by the Yunnan Machinery Import and Export 
Corporation (YMIEC) in March 2005. Its installed capacity of power generation (280 MW) surpasses that of Baluchaung (168 MW), which had long been the biggest power source and which was constructed by Japanese companies with Japanese war reparations and economic cooperation after World War II. The Paunglaung Dam Project was the YMIEC's biggest undertaking. Indeed, it was the largest hydro-power plant China had exported to South-East Asia and Yunnan's largest foreign-trade project. The total cost of the project was estimated at \$US160 million, which was financed by the Export-Import Bank of China (China Exim Bank).

As of March 2006, Myanmar had 11 major continuing hydro-power projects, with a total generating capacity of $1734 \mathrm{MW}$. Contracts were signed for seven projects and all were with Chinese enterprises. The largest project is the Yeywa hydro-power plant south of Mandalay, with a capacity of $790 \mathrm{MW}$. Yeywa will cost \$US700 million. In August 2003, the China Exim Bank approved a \$US200 million loan at preferential interest rates for the project (Bosshard 2004). The China Water Resources and Hydropower Construction Group (Sinohydro) and the China International Trust and Investment Corporation (CITIC) won contracts to provide generators and other equipment for the project. In addition to low-priced machinery and equipment and services, long-term and low-interest loans and export credits offered by public financial institutions made it possible for Chinese enterprises to become major players in this field.

Another example of significant Chinese economic cooperation in infrastructure development is the Ayeyarwady Transportation Project, which provides a transport line from Yunnan Province to Thaliana Port near Yangon. This project apparently started in October 1999, when a high-level Chinese delegation accompanied by Khin Nyunt visited Bam, the navigation head on the Ayeyarwady River. This project includes three infrastructure developments: constructing a container port near Bhamo, upgrading the road from the new container port to Muse/Lwejel on the Chinese border and dredging the river to ensure a safe shipping lane. The Myanmar Port Authority plans to transport two million containers a year in the future. ${ }^{16}$ It also plans to construct a container yard, office buildings, residences and other amenities in the hinterland. ${ }^{17}$

Yunnan Province obviously seeks a direct route through Myanmar to a seaport from which it can export products to South Asia, the Middle East and Europe. Such an outlet would reduce transport costs and time and would bypass the Malacca Strait in the event of a conflict in the South China Sea (Malik 1998). With the completion of the project, the Ayeyarwady will link China's south-western frontier with the Bay of Bengal and the Andaman Sea. 


\section{State-owned economic enterprises}

Since the beginning of the twenty-first century, the Myanmar Government has accelerated the construction of new state-owned factories (Kudo 2005a). The number of such factories increased by only 19 for the five years between fiscal years 1985/86 and 1990/91, but by 92 for the next five fiscal years, 1990/91-95/96, and by about 20-30 a year up to 2000. Thereafter there was impressive growth, with 53 public industrial enterprises set up in the fiscal year 2001/02 and 231 in 2002/03. Most of the new factories are for import-substitution industries that target domestic markets. Such a policy shift probably reflects the Myanmar Government's drive towards self-sufficiency in the agricultural and industrial sectors. ${ }^{18}$

China's economic cooperation programs strongly supported the massive construction of state-owned factories such as textile mills, plywood plants, rice mills, pulp and paper mills, sugar mills, agricultural equipment factories and other light manufacturing facilities. Table 6.7 shows examples of the Ministry of Industry Number One's factories that were constructed with the provision of Chinese financial and technical support and their machinery and equipment. Without Chinese support, these factories would never have materialised.

Myanmar's SEEs, however, have a long history of inefficiency, poor management and vulnerability to all the ills that plague public enterprises, including rent-seeking activities and corruption (Kudo 2005a). The SEEs are highly controlled by the central government in financial and managerial terms. With the lack of financial and managerial autonomy, newly built state-owned factories would not operate efficiently. For example, Japan was the top donor country to Myanmar, with its contributions accounting for 66.7 per cent of the total bilateral overseas development assistance (ODA) received by Myanmar between 1976 and 1990 (Kudo 1998:Table 1). Myanmar consistently ranked within the top-10 recipients and often ranked within the top five. A large portion of Japanese ODA was directed to the so-called Four-Industries Project through Myanmar Heavy Industries, a SEE under the Ministry of Industry Number Two. This project was to become self-reliant once ODA was suspended. In the end, most Japanese ODA provided to Myanmar turned into bad loans. This time around, proliferating state-owned factories could become a burden on the government budget, and eventually become bad loans for the Chinese stakeholders. 
Table 6.7 New Myanmar Ministry of Industry Number One factories built with Chinese cooperation

\begin{tabular}{|c|c|c|c|}
\hline Factory type & Location & Completion date & Contractor \\
\hline \multicolumn{4}{|l|}{ Textile industry } \\
\hline Garment factory & Kyaukse & January 2003 & $\begin{array}{l}\text { China World Best Group Co. } \\
\text { Ltd }\end{array}$ \\
\hline Textile factory & Pwintphyu & March 2005 & $\begin{array}{l}\text { Tianjin Machinery Import and } \\
\text { Export Corporation }\end{array}$ \\
\hline Textile factory & Pakkoku & October 2005 & $\begin{array}{l}\text { Tianjin Machinery Import and } \\
\text { Export Corporation }\end{array}$ \\
\hline Textile factory & Salingyi & November 2005 & $\begin{array}{l}\text { China National Construction } \\
\text { and Agricultural Machinery } \\
\text { Import and Export } \\
\text { Corporation }\end{array}$ \\
\hline Garment factory & Taungtha & January 2006 & $\begin{array}{l}\text { China World Best Group Co. } \\
\text { Ltd }\end{array}$ \\
\hline 200 looms extension plant & Myintgyan & December 2004 & n.a. \\
\hline 400 looms extension plant & Yamethin & January 2005 & n.a. \\
\hline \multicolumn{4}{|c|}{ Paper and chemical industries } \\
\hline Paper factory (3) & Palate & January 2001 & $\begin{array}{l}\text { Tianjin Machinery Import and } \\
\text { Export Corporation }\end{array}$ \\
\hline $\begin{array}{l}\text { Bleached bamboo-pulp } \\
\text { factory }\end{array}$ & Thabasung & May 2005 & $\begin{array}{l}\text { China Metallurgical } \\
\text { Construction Group } \\
\text { Corporation }\end{array}$ \\
\hline \multicolumn{4}{|l|}{ Ceramics industry } \\
\hline Refractory brick factory & Kyaukse & December 2005 & $\begin{array}{l}\text { China National Building } \\
\text { Machinery and Equipment } \\
\text { Corporation }\end{array}$ \\
\hline Cement factory & Kyaukse & January 2003 & $\begin{array}{l}\text { China National Construction } \\
\text { and Agricultural Machinery } \\
\text { Import and Export } \\
\text { Corporation }\end{array}$ \\
\hline $\begin{array}{l}\text { Kiln production line }(300 \\
\text { TPD) }\end{array}$ & Kyaukse & August 2005 & n.a. \\
\hline \multicolumn{4}{|l|}{ Foodstuff industries } \\
\hline Instant-noodle factory & Sagaing & July 2001 & $\begin{array}{l}\text { Karehua Noodle Line } \\
\text { Machinery Co. Ltd }\end{array}$ \\
\hline
\end{tabular}

Note: List includes factories completed after 2001 only. This list might not cover some factories that were not reported in the media.

Source: New Light of Myanmar, Myanmar Times and other press. Compiled by JETRO Yangon Office.

\section{Energy development}

As its economy grows rapidly, China's quest for energy sources abroad has expanded. Myanmar's oil and gas reserves have naturally attracted China's attention. China's presence in Myanmar's oil and gas fields has, however, been observed only recently. The China National Offshore Oil Corporation (CONIC) signed six contracts for production sharing with the Myanmar Oil and Gas Enterprise (MOGEN) of the Ministry of Energy from October 2004 to January 2005. ${ }^{19}$ The China Petroleum and Chemical Corporation (SINOPEC) and its subsidiary Dian Quantum Petroleum Exploration also work the inland fields. Moreover, CONIC and its subsidiary Chimney Assets also won contracts to upgrade the four old oilfields in central Myanmar. 
These companies are now at various stages of exploration and they have already made financial commitments of \$US163 million. The Chinese investment is rather small compared with the total amount of foreign investment in Myanmar's oil and gas sector of \$US2.635 billion - the largest recipient of foreign investment accounting for 34 per cent of the total outstanding up to March $2006 .{ }^{20}$ It is only recently, however, that Chinese companies have started to invest vigorously in Myanmar. Of 26 Chinese foreign investments in Myanmar overall, 16 projects were made either in the fiscal year 2004/05 or 2005/06, representing nearly 70 per cent in terms of investment value. Most of those were invested in the energy and mining sectors.

Another big project is Petro China's plan to build a gas pipeline from the Shwe gas field off the coast of Rakhine State to Yunnan Province. The Shwe field comprises several large blocks, containing about 200 billion cubic metres of gas. Petro China signed a memorandum of understanding with Myanmar Oil and Gas Enterprise (MOGE) to buy gas from the Shwe fields for 30 years starting from 2009.

Myanmar already exports natural gas to Thailand via a pipeline, and gas exports reached \$US2.25 billion in 2007, becoming by far Myanmar's biggest foreign exchange earner. Myanmar will have another big source of foreign earnings from gas exports to China in the near future. Moreover, oil and gas exports offer the Myanmar Government a diplomatic advantage over its neighbouring countries; indeed, India also made great efforts to secure Myanmar's gas from the same field. India eventually reached an agreement with Myanmar to purchase the gas with more favourable conditions based on a 'take-or-pay' arrangement, by which India gives Myanmar guaranteed earnings every year even if it is not able to access the gas. Myanmar has come out the winner in the Sino-India rivalry for energy.

\section{Conclusion: who benefits and who pays?}

Against the background of closer diplomatic, political and security ties between Myanmar and China since 1988, their economic relations have also grown stronger throughout the 1990s and up to the present. China is now a major supplier of consumer goods, durables, machinery and equipment and intermediate products to Myanmar. China also offers markets for Myanmar's exports such as timber, agricultural produce, marine products, minerals and, recently, natural gas. Border trade provides a direct route connecting central Upper Myanmar to Yunnan Province in China. Physical infrastructure developments such as roads and bridges and institutionalisation of cross-border transactions, including one-stop services, promote border trade. Without the massive influx of Chinese products, the Myanmar economy could have suffered more severe shortages of commodities. 
China also provides a large amount of economic cooperation and commercial-based financing in the areas of infrastructure, SEEs and oil and gas exploitation. Without Chinese long-term loans with low interest rates, the Myanmar Government could not have implemented its massive construction of new state-owned factories such as textile and sugar mills. Although China's official foreign investment is rather small, it is not insignificant. It has recently poured money into oil and gas exploration and Chinese enterprises could soon be major players in this booming field in Myanmar. There can be no doubt that Myanmar's economy is now heavily dependent on economic ties with China.

The lop-sided trade with China has, however, failed to have a substantial impact on Myanmar's broad-based economic and industrial development. About 70 per cent of Myanmar's exports to China is timber in the form of logs or roughly sawn timber. Wood extraction and its export are quite different from other major export items such as beans and pulses and garments, as the latter has induced the improved utilisation of existing factors of production such as land and labour in the whole economy. In contrast, timber exports are no more than exploitation of a limited natural resource that happened to remain untapped during Myanmar's past as a closed economy.

Moreover, Chinese firms could exploit natural resources in Myanmar excessively without considering environmental sustainability. Myanmar ranked seventy-eighth for China's imports and its share constituted only 0.04 per cent in 2007. Even though China is the most important trading partner for Myanmar, Myanmar is not such a significant trading partner for China. China and Chinese firms have little incentive to pay much attention to the sustainability of Myanmar's export commodities or to the environmental impacts of such exports to China. Chinese firms can shift their import sources from Myanmar to another country. Myanmar benefits from trading with China in the short run, but it could lose from it in the long run.

China's economic cooperation and commercial loans also apparently support the present regime, but their effects on the whole economy will be limited under an unfavourable macroeconomic environment and a distorted incentives structure. In particular, the newly built state-owned factories could become a burden on the Myanmar Government's budget and eventually represent bad loans for the Chinese stakeholders. Myanmar's debt arrears accumulated to \$US100 million by 2003 and, in 2005, the China Export and Credit Insurance Corporation (SINOSURE) ${ }^{21}$ rated Myanmar eighth of nine in country-risk ratings (in which the first rank indicates the safest countries and the ninth indicates the most risky countries) (Bi 2008a). Moreover, Wilson (2007:87-90) argues, mentioning several examples, that China's 'embrace' of Myanmar is by no means open-ended and China has not always achieved its goals. Chinese stakeholders, including Chinese taxpayers, might have to pay the debts at the end of the day. 
All in all, strengthened economic ties with China are instrumental for the survival of the Myanmar regime in the midst of economic sanctions by Western nations. They are not, however, a powerful force promoting the process of broad-based economic development in Myanmar. After all, Myanmar people could be the losers, since they have to live under a repressive regime that might not have survived this long without Chinese support.

\section{References}

Akimoto, Y. 2004, 'Hydro-powering the regime', Irrawaddy, Online edition, $<$ http://www.irrawaddy.org/aviewer.asp?a=3757\&print=yes\&c=e>

Bi, Shihong 2008a, 'China's economic cooperation with Myanmar', in Toshihiro Kudo (ed.), An Investigation into the Myanmar Economy: How the military government has survived, (In Japanese), IDE Selection No. 12, Institute of Developing Economies, JETRO, Chiba.

Bi, Shihong 2008b, 'Border economic activities between Yunnan Province and Laos, Myanmar and Vietnam', in Masami Ishida (ed.), A study on Mekong regional development: emerging border economic zones, (In Japanese), Research Report No. 2007-IV-23, Institute of Developing Economies, METRO, Chiba.

Bosshard, P. 2004, China Exim Bank and China Development Bank Case Studies, International Rivers Network, $<$ http://www.irn.org/programs/china/Exim_Bank.pdf $>$

Central Statistical Organisation 2003, Statistical Yearbook, 2003, Central Statistical Organisation, Yangon.

Department of the Myanmar Language Commission (DMLC) 1993, Myanmar-English Dictionary, Ministry of Education, Yangon.

Ebashi, Masahiko 2006, 'A note on Myanmar's situation after Khin Nyunt's ouster', SPF Voices from the World, On-Demand Publication Series, Sasakawa Peace Foundation.

Fujita, K. and Okamoto, I. 2006, Agricultural policies and development of Myanmar's agricultural sector: an overview, IDE Discussion Paper Series No. 63, Institute of Developing Economies, JETRO, $<$ http://www.ide.go.jp/English/index4.html>

Global Witness, 2005, A Choice for China: Ending the destruction of Burma's northern forests, <http://www.globalwitness.org/reports/show.php/en.00080.html>

Hao, H. M. 2008, 'China's trade and economic relations with CLMV', in Sotharith Chap (ed.), Development strategy for CLMV in the age of economic 
integration, ERIA Research Project Report 2007, no. 4, Institute of Developing Economies, JETRO, Chiba.

Hlaing, K. Y. 2005, 'Myanmar in 2004: why military rule continues', Southeast Asian Affairs 2005, Institute of Southeast Asian Studies, Singapore.

International Monetary Fund various issues, Direction of Trade.

Jannuzi, Frank S. 1998, 'The new Burma Road (paved by polytechnologies?)', in Robert I. Rotberg (ed.), Burma: Prospects for a democratic future, Brookings Institution Press, the World Peace Foundation and Harvard Institute for International Development, Washington, DC.

Kobayashi, Takaaki 2007, 'China's foreign aid policy: development and reforms', Journal of JBIC Institute, no. 35, October, pp. 109-47.

Kudo, Toshihiro (ed.) 2008, An Investigation into the Myanmar Economy: How the military government has survived, (In Japanese), IDE Selection No. 12, Institute of Developing Economies, JETRO, Chiba.

Kudo, Toshihiro 1998, 'Political basis of economic policies under Burmese socialism', Southeastern Asian Studies, no. 4, Tokyo University of Foreign Studies, pp. 139-77.

Kudo, Toshihiro 2005a, Stunted and distorted industrialization in Myanmar, IDE Discussion Paper Series No. 38, Institute of Developing Economies, JETRO, < http://www.ide.go.jp/English/index4.html>

Kudo, Toshihiro 2005b, The impact of United States sanctions on the Myanmar garment industry, IDE Discussion Paper Series No. 42, Institute of Developing Economies, JETRO, $<$ http://www.ide.go.jp/English/index4.html>

Lintner, B. 1990, The Rise and Fall of the Communist Party of Burma (CPB), Southeast Asian Program, Cornell University, Ithaca.

Lintner, B. 1994, Burma in Revolt: Opium and insurgency since 1948, Westview Press and White Lotus, Boulder, San Francisco, Oxford and Bangkok.

Lintner, B. 1998, 'Drugs and economic growth: ethnicity and exports', in Robert I. Rotberg (ed.), Burma: Prospects for a democratic future, Brookings Institution Press, the World Peace Foundation and Harvard Institute for International Development, Washington, DC.

Malik, J. M. 1998, 'Burma's role in regional security-pawn or pivot?', in Robert I. Rotberg (ed.), Burma: Prospects for a democratic future, Brookings Institution Press, the World Peace Foundation and Harvard Institute for International Development, Washington, DC.

Myanmar Times various issues, (weekly English magazine). 
Myint, H. 1959, "The "classical theory" of international trade and the underdeveloped countries', Economic Journal, vol. 68, pp. 317-37.

New Light of Myanmar various issues, (state-run daily English newspaper).

Ott, M. C. 1998, 'From isolation to relevance: policy considerations', in Robert I. Rotberg (ed.), Burma: Prospects for a democratic future, Brookings Institution Press, the World Peace Foundation and Harvard Institute for International Development, Washington, DC.

Selth, A. 1996, Transforming the Tatmadaw: the Burmese armed forces since 1988, Canberra Papers on Strategy and Defence No. 113, Strategic and Defence Studies Centre, Research School of Pacific and Asian Studies, The Australian National University, Canberra.

Than, M. 2005, 'Myanmar's cross-border economic relations and cooperation with the People's Republic of China and Thailand in the Greater Mekong Subregion', Journal of GMS Development Studies, vol. 2, no. 1, October.

Than, T. M. M. 2003, 'Myanmar and China: a special relationship?', Southeast Asian Affairs 2003, Institute of Southeast Asian Studies, Singapore.

Wilson, T. 2007, 'Foreign policy as political tool: Myanmar 2003-2006', in M. Skidmore and T. Wilson (eds), Myanmar: The State, community and the environment, Asia Pacific Press, Canberra. 


\section{Appendix 1: Bilateral agreements between Myanmar and China since 1996}

\section{SPDC Chairman Than Shwe's visit to China (January 1996)}

Agreement on Economic and Technical Cooperation

Protocol on Cultural Cooperation

Framework Agreement on Provisions of Interest for Subsidised Credit

State Councillor Luo Gan's visit to Myanmar (March 1997)

Agreement on Myanmar-China Border Area Management and Cooperation

Agreement on the Chinese Government Providing a Grant of RMB5 million to Myanmar

Agreement on Supply of Agricultural Machinery, Equipment and Spare Parts and Technical Cooperation

Vice-Premier of State Councillor Wu Bangguo's visit to Myanmar (October 1997)

Framework Agreement on a Preferential Loan with Interest Subsidised by the Chinese Government

Vice-Foreign Minister Tang Jiaxuan's visit to Myanmar (January-February 1998)

Agreement on Mutual Exemption on Visas for Holders of Diplomatic and Official (Service) Passports

SPDC Secretary-1 Khin Nyunt's visit to China (June 1999)

Agreement on Economic and Technical Cooperation

SPDC Vice-Chairman Maung Aye's visit to China (June 2000)

Joint Statement on the Framework for the Future of Bilateral Relations and Cooperation

Vice-President Hu Jintao's visit to Myanmar (July 2000)

Agreement on Economic and Technical Cooperation

Agreement on Tourism Cooperation

Agreement on Science and Technology Cooperation

SPDC Secretary-3 Win Myint's visit to China (October-November 2000)

Memorandum of Understanding between the Union Solidarity and Development Association (USDA) and the All China Youth Federation (ACYF)

Minister for Home Affairs Jia Chunwang's visit to Myanmar (January 2001)

Memorandum of Understanding on Narcotic Drugs Control

Minister for Land Resources Tian Fengshan's visit to Myanmar (July 2001)

Memorandum of Understanding on Cooperation in the Geological and Mineral Resources Sectors

Vice-Foreign Minister Wang Yi's visit to Myanmar (August 2001)

Agreement on Economic and Technical Cooperation

President Jiang Zemin's visit to Myanmar (December 2001)

Agreement on Phytosanitary Cooperation

Agreement on Cooperation in Fisheries

Contract for Improving Petroleum Recovery on IOR-4, Pyay Field

Protocol for Cooperation in Border Area

Agreement on Economic and Technical Cooperation

Agreement on the Promotion and Protection of Investment

Agreement on Cooperation in Animal Health and Quarantine

SPDC Chairman Than Shwe's visit to China (January 2003)

Agreement on Health Cooperation

Agreement on Economic and Technical Cooperation

Agreement on Cooperation in the Field of Sports

Vice-Premier Li Lanqing's visit to Myanmar (January 2003)

Agreement on Partial Debt Relief for Myanmar

Memorandum of Understanding on Extending a Grant for the Supply of Culture, Education and Sporting

Goods by China to Myanmar

Memorandum of Understanding on the Program of Aerospace and Maritime Courses Provided by China to Myanmar

Vice-Premier Wu Yi's visit to Myanmar (March 2004) 


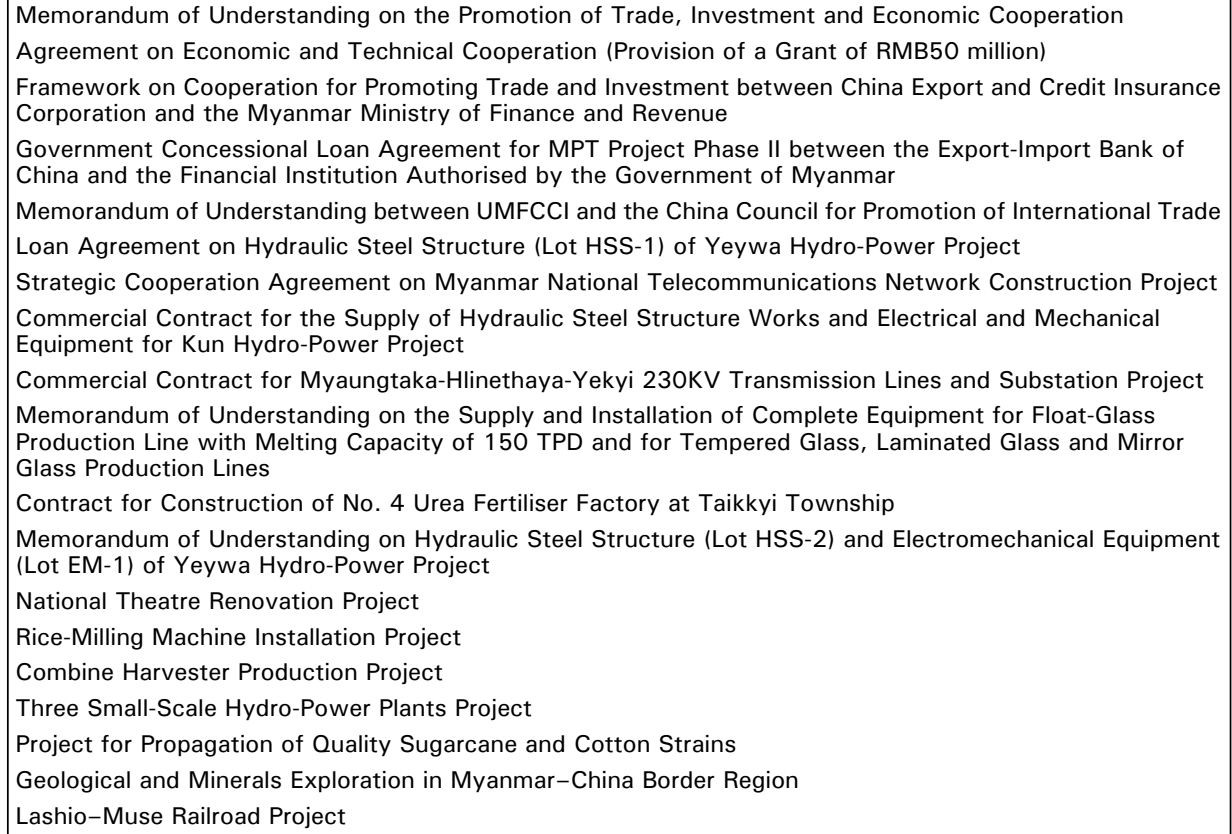

\section{Endnotes}

1 According to DMLC (1993:266), paukphaw means '1. sibling, 2. intimate, and is an affectionate term conferred upon the Chinese by the Myanmar people'.

2 For further detail, see Lintner (1990 and 1994).

3 Lintner (1990:45) reports that a major reason why the mutiny did not happen earlier was that the ordinary soldiers and local commanders were uncertain about China's reaction to such a move.

4 Imports from Japan made up nearly 40 per cent of Myanmar's total imports before 1988, due mainly to supplies related to Japan's economic cooperation programs. Japan suspended most aid after the political unrest of 1988, except for a few continuing projects. Without full-fledged overseas development aid programs, its share declined remarkably to only 2.7 per cent in 2006.

5 Statistics Canada constructs the World Trade Database based on the United Nations' Commodity Trade Statistics Database (UN Comtrade), and the database-retrieval services are used for Tables 6.3 and 6.4.

6 Data from China Customs are classified by the Harmonised Commodity Description and Coding System (HS); HS 44 represents 'Wood'.

7 See Kudo (2005b), who provides a detailed account of the growth and decline of Myanmar's garment industry in the 1990s and up to 2005.

8 The fiscal year starts in April and ends in March of the next year.

9 SITC stands for Standard International Trade Classification.

10 District-wide figures have been available since 1999.

11 There are five trade posts on the Myanmar side of the border with Yunnan Province: Muse (mile 105), Lwejel, Laiza, Kanpeiktee and Chinshwehaw. Among them, Muse is the most lucrative in terms of the volume of trade, accounting for 87 per cent of the total in 2002 (Than 2005:44).

12 Mya Than (2005:40) provides five definitions of cross-border trade: formal or official border trade, informal border trade, illegal border trade (smuggling), transit trade and barter trade. He also points out that all statistics on border trade are usually underestimated.

13 A small part of the road was constructed and owned by another private company, Diamond Palace. That company was said to have been owned by military intelligence headed by Khin Nyunt, then Secretary No. 1 of the SPDC. The Myanmar military saw the strategic importance of the road and intended to avoid full ownership and operation by one private company. 
14 Details of the new system, however, are not known to the author.

15 For details, see Akimoto (2004).

16 Interview with the Myanmar Port Authority in Bhamo, September 2002.

17 The implementation of the project has apparently been delayed due to disputes between the two countries on levying customs duties (Wilson 2007:88) and national flags flying on vehicles. A Chinese specialist reports, however, that the project will be implemented between 2011 and 2015 (Bi 2008b).

18 The agricultural policy of Myanmar has exhibited a strong inclination towards self-sufficiency; see Fujita and Okamoto (2006).

19 Information is from New Light of Myanmar, Myanmar Times and other media.

20 It is said that there is a large number of informal Chinese investments and businesses in Myanmar, most of which operate under the names of Myanmar citizens. Such cases do not appear in the Myanmar Investment Commission (MIC) statistics.

21 SINOSURE is the only policy-oriented Chinese insurance company specialising in export credit insurance. It started operation on 18 December 2001. SINOSURE offers coverage against political and commercial risks (SINOSURE web site, viewed February 2008). 